\title{
Structural, Process and Curriculum Quality of Day Care and Preschool Provisions in the Netherlands ${ }^{1}$
}

\begin{abstract}
The presented study investigated the structural, process and curriculum quality in Dutch Early Childhood Education and Care (ECEC) system. Teachers ( $=46$ ) completed a structured questionnaire about the teacher, classroom and center characteristics. Furthermore, the Classroom Assessment Scoring System (CLASS) Toddler was used to measure the process quality in 28 Dutch day care and preschool provisions considered to be good practices. Results regarding structural quality revealed small significant differences between day care and preschool provisions for teacher's educational level, children-to-teacher ratio, and classroom composition. As regards process quality, the results showed moderate to high Emotional Support and moderate levels of Support for Learning in both types. No significant differences were identified in process quality between day care and preschool classrooms. Finally, the teachers reported placing the greatest emphasis on activities involving pretend play, self-regulation and language and fewer opportunities concerning literacy, maths and science activities, with no significant differences between the two provisions.
\end{abstract}

Keywords: Early Childhood Education and Care, structural quality, process quality, CLASS Toddler, curriculum, caregivers.

\footnotetext{
* Faculty of Social Sciences, Utrecht University.

** Faculty of Social Sciences, Utrecht University.

1 This study has received funding from the European Union's Seventh Framework Programme for research, technological development and demonstration under contract number FP7-SSH-2013-2 (ecec-care.org).
} 


\title{
Strukturalna, procesowa i programowa jakość w holenderskich ośrodkach opieki dziennej i przedszkolnej
}

\begin{abstract}
Abstrakt
W przedstawionym projekcie naukowym zbadano jakość strukturalną, procesową i programową holenderskiego systemu Wczesnej Edukacji i Opieki nad Dzieckiem (ECEC). Nauczyciele ( $\mathrm{N}=46)$ wypełnili ustrukturyzowany kwestionariusz dotyczący cech nauczyciela, klasy i ośrodka. Następnie wykorzystano system Classroom Assessment Scoring System (CLASS) Toddler do zmierzenia jakości procesowej w 28 holenderskich ośrodkach świadczących usługi w ramach opieki dziennej i przedszkolnej uznawanych za przykład „dobrej praktyki”. Wyniki dotyczące jakości strukturalnej ujawniły niewielkie znaczące różnice między ośrodkami zajmującymi się opieką dzienną a placówkami przedszkolnymi w kwestii poziomu wykształcenia nauczyciela, liczby dzieci przypadającej na każdego nauczyciela i rodzaju dzieci w klasie. Jeśli chodzi o jakość procesową, wyniki badania wykazały wsparcie emocjonalne na poziomie od umiarkowanego do wysokiego i umiarkowane poziomy wsparcia uczenia się w obu typach placówek. Nie stwierdzono znaczących różnic w jakości procesowej pomiędzy ośrodkami zapewniającymi opiekę dzienną a placówkami przedszkolnymi. Nauczyciele zgłaszali, że kładą największy nacisk na zabawę w odgrywanie ról, samokontrolę i umiejętności językowe oraz mniejsze możliwości w zakresie ćwiczenia umiejętności czytania i pisania, matematyki i nauk ścisłych. Nie stwierdzono jednak znaczących różnic w tym zakresie między badanymi rodzajami placówek.
\end{abstract}

Słowa kluczowe: wczesna edukacja i opieka nad dzieckiem, jakość strukturalna, jakość procesowa, CLASS Toddler, program nauczania, opiekunowie.

Enrollment in Early Childhood Care and Education [ECEC] is beneficial for children's development, especially when they experience high quality interactions with the teacher (Burchinal, Vandergrift, Pianta, Mashburn 2010: 173; Mashburn et al. 2008: 743; Pianta, Barnett, Burchinal, Thornburg 2009: 49; Sylva, Melhuish, Sammons, Siraj-Blatchford, Taggart 2011: 119). Previous studies have shown positive effects of ECEC quality on children's outcomes in various domains, including behavioural, cognitive, social and emotional development (Broekhuizen, van Aken, Dubas, Mulder, Leseman 2015: 226; Cadima, Leal, Burchinal 2010: 474; Côté et al. 2013: 761; Curby, Brock, Hamre 2013: 304; Mashburn et al. 2008: 743; Sylva et al. 2011: 119). A distinction is often made between structural and process quality. Structural quality refers to teacher or classroom characteristics, for example teacher educational qualifications, group-size and children-to-teacher ratio. Process quality refers to dynamic aspects of the classroom or the interactions between children and teachers (La Paro, Hamre, Pianta 2011: 1; Thomason, La Paro 2009: 
286). Structural quality aspects are considered preconditions for process quality and therefore affect children's wellbeing and development indirectly - whereas process quality is seen as a direct determinant for child outcomes (Leseman, Veen 2016: 107). Before specifying the aims of the study, we will provide more information on the Dutch child care context.

\section{Early Childhood Care and Education in the Netherlands}

Currently, approximately $80 \%$ of two- and three-year-olds attend some form of center-based ECEC (OECD 2015: 23). The Dutch ECEC system consists of two main types of provision before formal schooling starts at the age four years when all children enroll in kindergarten. The first type is center-based day care for children from the age of three months. These centers provide non-parental care for young children and are open for 5 days a week and 11 hours a day. However, on average, children attend day care for 2 full days a week (Akgündüz, Plantenga 2012: 2; NCKO 2011: 1). The major reason for this part time use is the part time employment of mothers, which is very common in the Netherlands. Parents of children attending day care facilities are generally highly educated, which is explained by the relatively high costs of formal care (Portegijs, van den Brakel, Hartgers, Akkermans 2016: 284). The second type concerns preschools (also known as playgroups) for twoand three-year-old children. They have similar opening hours as elementary schools split into morning and afternoon sessions. Children attend this type of provision for two to four half-days a week. Most preschools provide a targeted program for children from lower educated families or children with an immigration background. These special education programs emphasize emotional support, sensitivity to children's needs, and provide a mixture of play and pre-academic activities with an emphasis on language development. Disadvantaged children attend these preschools for about 10 to 15 hours a week, spread over 3 or 4 half days (Akgündüz, Plantenga 2012: 2), whereas non-disadvantaged children attend these preschools for 2 half days a week. Day care centers and preschools differ not only as regards the age range and socioeconomic background of the children, but also in their orientation (Slot, Leseman, Verhagen, Mulder 2015: 66). Day care centers traditionally show a stronger care orientation. This means that a lot of time is devoted to free play and care routines with few (educational) activities. In preschool centers stronger emphasis is placed on education with the provision of more structured educational activities, mainly because of the educational programs that are used (Helmerhorst, Riksen-Walraven, Vermeer, Fukkink, Tavecchio 2014: 772). However, with the implementation of the new Act OKE (Promoting Development through Quality and Education) in 2010 both types of provisions are brought under the same statutory quality framework emphasizing the importance of both 
social-emotional and cognitive outcomes for children (Leseman, Slot 2013: 7). As a result, the orientations of both types of provisions are more aligned now and the differences in quality have largely disappeared, particularly for structural quality (Slot et al. 2015: 66).

\section{Structural quality in Dutch ECEC}

The Dutch Childcare Act of 2005 prescribes a children-to-teacher ratio of 6:1 for two- and three-year-old children and a ratio of 8:1 for three- and four-year-old children. The maximum group size is 12 children for two-year-olds and 16 children for three-year-olds (Convenant Kwaliteit Kinderopvang en Peuterspeelzalen 2013: 23,31 ). Furthermore, teachers are required to have completed a minimum of threeyear training in a relevant vocational training program (Slot et al. 2015: 66). The Dutch ECEC system is strongly regulated, especially concerning these structural characteristics. Quality monitoring and inspection is carried out by the municipal health services.

Additionally, the education programs that are used in preschools as part of addressing early disparities in children need to be approved by the national Accreditation Committee for Child and Youth Interventions of the Netherlands Youth Institute (www.nji.nl). The majority of day care centers and virtually all preschools use (parts of) these programs to shape daily practice (Slot et al. 2015: 69). Although these programs differ in how teachers are trained and monitored, they all aim at broad developmental and educational goals.

\section{Process quality in Dutch ECEC}

Process quality refers to children's experiences in ECEC and involves social teacherchild and child-child interactions while engaging in play and daily provided routines and activities. The quality of interactions can be divided into different aspects. Emotionally supportive interactions refer to general positive climate in the classroom and the extent to which a teacher responds in a sensitive and responsive way to children's needs while taking into account their desires and initiatives. Another aspect concerns the degree to which teachers support children in developing self-regulation skills and classroom-appropriate behavior. Finally, the educational aspects of interactions concern the teacher's support of children's development and the provision of learning opportunities during play and activities. Two influential studies investigated the process quality of Dutch ECEC provisions. Both of them showed that aspects of emotional and behavioral support were generally moderate, whereas educational quality was low to moderate (e.g. Helmerhorst et al. 2014: 784; Helmerhorst, Riksen-Walraven, Gevers Deynoot-Schaub, Tavecchio, Fukkink 2015: 101; Leseman, Veen 2016; Slot et al. 2015: 70; Slot, Boom, Verhagen, 
Leseman 2017: 83). This reflects a typical pattern found in many other countries as well, including England, Finland, Germany, Italy, Poland, Portugal and the United States (La Paro, Williamson, Hatfield 2014: 887; Pakarinen et al. 2010: 117; Sylva, Pastori, Lerkkanen, Ereky-Stevens, Slot 2016: 10; von Suchodoletz, Fäsche, Gunzenhauser, Hamre 2014: 514; Thomason, La Paro 2009: 296). Regarding emotional quality there were no differences discovered between day care and preschool classrooms, whereas the educational quality was slightly higher in preschool classrooms (Leseman, Veen 2016: 108; Slot et al. 2017: 89).

Internationally, ECEC quality has been shown to be related to children's behavioural, cognitive, social and emotional outcomes (Cadima, Leal, Burchinal, 2010: 474; Côté et al. 2013: 761; Curby et al. 2013: 304; Mashburn et al. 2008: 743; Sylva et al. 2011: 119). Initial evidence from the Netherlands supports these findings both in the short and in the longer term. A study in Dutch day care centers showed positive concurrent relations between the aspect of emotional and educational quality and children's social competence (Helmerhorst et al. 2014: 783). Another study revealed that higher emotional quality was related to better social competence in three year old children who attended day care centers (Broekhuizen et al. 2015: 226) and better vocabulary skills (Slot, Broekhuizen, Leseman, Veen 2015: 81), while controlling for children's prior skills at the age of two. Higher educational quality was associated with growth in selective attention (i.e. the ability to focus attention without getting distracted by other stimuli) in three-year-old children (Slot, Broekhuizen et al. 2015: 82), which persisted into longer-term effects three years later (Mulder, Boom, Slot, Verhagen, Paul Leseman 2016: 53). Higher emotional and educational quality were both related to growth in children's selective attention skills from the age of three to five years (Mulder et al. 2016: 53).

Another aspect of process quality is the provision of developmental and preacademic activities, also referred to as the implemented curriculum. According to Pauline Slot et al. (2015: 65) the provision of such activities is a relatively understudied aspect of ECEC quality, while in fact these activities directly influence children's experiences (Slot et al. 2015: 66). A range of developmental and preacademic activities can be provided, as part of the implemented curriculum, including play, self-regulation, language or math activities (Slot et al. 2015: 66; Leseman, Veen 2016). Previous studies had shown the benefits of the provision of particularly language, literacy and math activities in the targeted domains (Clements, Sarama 2007: 158; Dickinson, Caswell 2007; Domitrovich et al. 2009: 255; Fantuzzo, Gadsden, McDermott 2011: 783; Lonigan, Farver, Philips, Clancy-Menchetti 2011: 328). Also the provision of activities focused on children's social-emotional development has shown positive effects in this area of development (Domitrovich, Cortes, Greenberg 2007: 593). The findings from the pre-COOL study illustrated the positive effects of enriching children's (pretend) play on children's vocabulary development, although only for children with a non-Dutch background (Verhagen, Mulder, Boom, Hoofs, Slot Leseman 2016: 66). 


\section{The present study}

The main aim of the present study is to investigate the structural, process and curriculum quality of Dutch day care and preschool provisions considered as good practice. Secondly, we will examine whether there are differences between day care and preschool provisions. A wide range of structural teacher and classroom features will be included, such as teacher's educational level, group size, children-toteacher ratio, classroom composition concerning the age and cultural background of children. To investigate process quality, a widely applied ECEC quality observation instrument, the Classroom Assessment Scoring System [CLASS] Toddler (La Paro et al. 2011), will be used. The CLASS Toddler evaluates classroom interactions based on two broad domains: Emotional Support and Engaged Support for Learning. Emotional Support reflects the overall climate in the classroom, teacher's sensitivity and responsiveness towards children's needs, and support for children's autonomy and self-regulation. Engaged Support for Learning reflects the abilities of the teacher to engage in interactions and activities with children that facilitate their development and learning.

\section{Method}

\section{Participants and procedures}

The present study is an extension study of the European multiple case study that was a part of the CARE project (Curriculum Quality Analysis and Impact Review of European ECEC; www.ecec-care.org). CARE investigated the quality and effectiveness of early childhood education and care (ECEC) and included 11 countries, covering all regions of Europe. However, for this study, only information about day care provisions and preschool education in the Netherlands was used.

The present study focused on provisions for two- and three-year-old children. The sample was recruited in the following way. First, the Utrecht University selected eleven ECEC (day care provisions and preschools) provisions identified as good practices. These good practices were based on the prior research or established contacts. A total of eleven ECEC selected centers were approached, ten of which agreed to participate in the Dutch extension of the CARE multiple case study. Next, managers of the organizations selected from one to three classrooms within each center resulting in a total sample of 28 classrooms (14 day care and 14 preschool classrooms). This convenience sample covered regional variation of urban and less urban areas across the Netherlands and as such represents variation in the socioeconomic background of children enrolled in these centers. The parents of the children in the selected classrooms were informed about the study with a letter and gave informed consent for participation in the study. 


\section{Structural classroom and center characteristics}

In order to collect structural information about the teacher, classroom and center characteristics, the teachers filled out a questionnaire. It was sent out during the same period as the observations were conducted. Information was obtained about teachers' gender, age, work experience, pre-service educational qualifications, and additional in-service training. Furthermore, data was obtained about the composition of the classrooms, such as the number of children and adults (the children-toteacher ratio was calculated based on this information), as well as age and cultural background of the children. For the cultural classroom composition, teachers reported on a three-point scale whether the majority of children was Dutch $(>80 \%$ was scored as 1) equally Dutch and non-Dutch (scored as 2) or the majority was non-Dutch ( $>80 \%$ was scored as 3 ).

\section{Observed process quality}

The CLASS Toddler (La Paro et al. 2011) was used to assess classroom process quality. It consists of eight dimensions that are rated on a 7 -point scale ranging from 1 or 2 (classroom is low on that aspect), through 3, 4 or 5 (classroom is in the midrange), to 6 or 7 (classroom is high on that aspect). Following the CLASS manual, two domains were distinguished (La Paro et al. 2011) Emotional Support and Engaged Support for Learning.

Emotional Support consists of five dimensions:

- "Positive Climate" reflects the warmth, enjoyment and respect displayed during teacher-child interactions;

- "Negative Climate" reflects the overall negativity expressed in the classroom by the teacher and the children (the scores are reversed);

- "Teacher Sensitivity" is the extent to which the teacher is aware, sensitive and responsive to children's needs;

- "Regard for Child Perspectives" captures the degree to which the teacher's interactions with children and classroom activities follow children's interests and the extent to which children's autonomy is encouraged; and

- "Behavior Guidance" refers to the teacher's ability to promote positive behavior and redirect problem behavior in the classroom.

Engaged Support for Learning captures three dimensions:

- "Facilitation of Learning and Development" considers how well the teacher facilitates play and activities to support children's learning and development;

- "Quality of Feedback" assesses the degree to which the teacher's feedback promotes learning and expands children's participation; and

- "Language Modeling" refers to the extent to which the teacher fosters, models and encourages children's use of language. 
The observers were four master's students from the Utrecht University that were trained by a licensed CLASS trainer and used the officially approved Dutch translation of the CLASS manual (Slot, Leseman, Mulder, Verhagen 2013). They achieved at least $80 \%$ agreement within one scale point with the CLASS trainer on each dimension in an online test, as recommended by the developers of the CLASS instrument. All the classrooms were visited during two regular mornings between February and July 2015. The visits lasted approximately three hours. During these visits, the master's students made videos of daily recurring activities in the morning. The observed activities represented and reflected the routines and activities part of the common day schedule of Dutch ECEC provisions. This included (1) indoor free play; (2) meal- or snack time; (3) educational and/or pre-academic activities, such as, circle time or reading a book and (4) creative activities, such as drawing or arts and crafts. This resulted in the total number of 112 videotaped activities (56 day care, 56 preschool). The videos lasted for 15 to 20 minutes. To evaluate the observed process quality, all the videos were coded with the CLASS Toddler within a six-month period after the training.

\section{Provision of developmental and pre-academic activities}

A structured questionnaire for teachers was used to assess the developmental and educational activities provided to two- and three-year old children that were extensively piloted for appropriateness and applicability in this age group (Slot et al. 2015: 69). To cover a broad range of activities, a total of eight scales were constructed. Pretend play and self-regulation are the first two scales, which are considered indicators of emotional process quality. The following six scales are regarded to be indicators of educational process quality, which are Language activities, Math activities, Science activities, and Pre-literacy activities. All scales were rated on a 7-point scale with scores ranging from 1 (never), 2 (less than twice a month), 3 (twice or thrice a month), 4 (weekly), 5 (two to four times a week), 6 (daily) and 7 (three or more times a day).

Pr e te n d p l a y (8 items; $\alpha=.93$ ) represents to what extent the teacher stimulates cognitive distancing, symbolizing and pretend in children by modeling behavior and encouraging children to participate in symbolic and pretend play. An example: "I show children how to use an object for something else then intended, for instance driving a wooden block as if it was a car".

Self-regulation (11 items; $\alpha=.87$ ) assesses the extent to which the teacher uses play, care routines and other activities to enhance children's behavioural self-regulation, for instance by talking about feelings and emotions, helping them resolve peer conflicts or playing games in which children have to take turns. An example: "When children have a conflict I let them express their own opinion so they better understand what the other person thinks". 
La n g u a g a c tiviti e s (7 items; $\alpha=.87$ ) assesses the average frequency of activities involving several forms of language use, including singing, rhyming, conversations, and vocabulary instruction. An example: "Having elaborate conversations about children's personal experiences, for instance what they did at the weekend".

$\mathrm{M}$ a th a ctiviti e s (12 items; $\alpha=.93$ ) assesses the average frequency of several math activities, for instance counting and sorting activities, and activities exploring different shapes. An example: "Counting how many objects one has, for example counting to five and saying 'I have five marbles'”.

Literacy activities ( 4 items; $\alpha=.81$ ) measures the average frequency with which activities are provided involving literacy and literacy materials. An example: "Asking the children questions about the content of the story during or after reading it".

S cience a ctivities (7 items; $\alpha=.90$ ) assesses the average frequency of several science activities, for instance, talking about subjects and activities exploring different phenomena related to nature or social sciences. An example: "Comparing different animals (in the zoo or a book), talking about similarities and differences (for example whether they live in warm or cold countries, whether they eat plants or meat, whether they are mammals or...)".

\section{Analysis strategy}

To investigate the structural and process quality and the provision of activities, descriptive statistics, such as mean and standard deviation scores and the range of scores were calculated for all these aspects. To address the second research question, independent-samples t-test and Pearson's chi-square tests of contingencies were used to test whether there were significant differences between the two provisions (day care and preschool).

\section{Results}

\section{Structural quality}

A total of 46 teachers (from 25 day care and 21 preschool classrooms, respectively) participated in the current study, providing information on 27 classrooms (14 day care, 13 preschool). Almost all teachers were women ( $96 \%$ of the day care teachers, $90.5 \%$ of the preschool teachers). The descriptive statistics on the classroom and center characteristics are presented in Table 1.

To compare structural aspects for the day care and preschool conditions, different analyses were conducted. Independent-samples t-test results first revealed that there are on average more teachers present in day care classrooms $(M=2.12$, 
$S D=.332)$ than in preschool classrooms, $(M=1.95, S D=.218), t(41.792)=2.053$, $p=.046$. Second, the children-to-teacher ratio was lower in day care classrooms $(M=6.9, S D=.9757)$ comparing to preschool classrooms, $(M=7.62, S D=.384)$, $t(44)=-3.173, p=.003$.

Table 1. Descriptive statistics for classroom and teacher characteristics

\begin{tabular}{|c|c|c|c|c|c|c|c|c|}
\hline & \multicolumn{4}{|c|}{ Day care } & \multicolumn{4}{|c|}{ Preschool } \\
\hline & $N$ & $M$ & $S D$ & Range & $N$ & $M$ & $S D$ & Range \\
\hline Group size & 25 & 14.44 & 1.66 & $12-16$ & 21 & 14.9 & 1.95 & $7-16$ \\
\hline Adults in the classroom & 25 & 2.12 & 0.33 & $2-3$ & 21 & 1.95 & 0.22 & $1-2$ \\
\hline Children-to-teacher ratio & 25 & 6.90 & 0.98 & $5.33-8$ & 21 & 7.62 & 0.38 & $7-8$ \\
\hline $\begin{array}{l}\text { Frequency }(N) / \text { Percent }(M) \\
\text { Age composition in the } \\
\text { classrooms }\end{array}$ & $N$ & $\%$ & & & $N$ & $\%$ & & \\
\hline 0 year & 6 & 24.00 & & & 0 & 0.00 & & \\
\hline 1 year & 10 & 40.00 & & & 0 & 0.00 & & \\
\hline 2 years & 25 & 100.00 & & & 21 & 100.00 & & \\
\hline 3 years & 25 & 100.00 & & & 21 & 100.00 & & \\
\hline 4 years & 9 & 36.00 & & & 1 & 95.2 & & \\
\hline $\begin{array}{l}\text { Cultural classroom } \\
\text { composition }\end{array}$ & & & & & & & & \\
\hline$>80 \%$ Dutch & 21 & 84.00 & & & 10 & 47.6 & & \\
\hline $50 \%$ Dutch / 50\% non Dutch & 2 & 8.00 & & & 3 & 14.3 & & \\
\hline$>80 \%$ non Dutch & 2 & 8.00 & & & 6 & 28.6 & & \\
\hline $\begin{array}{l}\text { Educational (highest) level } \\
\text { teacher }\end{array}$ & & & & & & & & \\
\hline $\begin{array}{l}\text { Secondary vocational } \\
\text { training or equivalent }\end{array}$ & 22 & 88.00 & & & 12 & 57.1 & & \\
\hline $\begin{array}{l}\text { Higher vocational training } \\
\text { or higher }\end{array}$ & 3 & 12.00 & & & 9 & 42.9 & & \\
\hline
\end{tabular}

Note: group size, age composition and children-to-teacher ratio data are based on the teachers' questionnaires.

Source: own research.

Also, Pearson's chi-square tests of contingencies (with $\alpha=.05$ ) were used to evaluate classroom composition and the education level of the teachers. First, a dummy variable was created for classroom composition. Given the low frequen- 
cies for both categories of a more mixed cultural classroom composition (50\% Dutch and 50\% non-Dutch or majority of non-Dutch children), these two categories were combined into one category. The results revealed differences in classroom composition between the two types of provision, $\chi^{2}(1, N=44)=5.10, p=.02$. Day care classrooms were more often composed of a majority of Dutch children, whereas preschool classrooms were more mixed. As regards teacher's pre-service qualifications, the results of the chi-square test revealed differences between both types $\chi^{2}$ $(1, N=46)=5.64, p=.02$. Teachers working in day care provisions more often had a secondary vocational training, whereas in preschools teacher's educational background was more balanced between secondary and higher vocational training. Finally, regarding the age composition in the classrooms, the results revealed differences between day care and preschool provisions. In day care provisions there were more 0 - and 1-year-old children (with $p=.025$, Fisher's exact test and $p=.001$, Fisher's exact test, respectively), whereas preschool classrooms more often had 4-year-old children ( $p=.013$, Fisher's exact test).

\section{Process quality}

The descriptive statistics on the CLASS dimensions are presented in Table 2.

Table 2. Descriptive statistics of the CLASS dimensions

\begin{tabular}{|l|c|c|c|c|c|c|c|c|}
\hline \multirow{2}{*}{} & \multicolumn{5}{|c|}{ Day care } & \multicolumn{5}{c|}{ Preschool } \\
\cline { 2 - 9 } & $M$ & $S D$ & Range & $N$ & $M$ & $S D$ & Range & $N$ \\
\hline CLASS Dimensions & & & & & & & & \\
Positive Climate & 5.71 & 0.97 & $3-7$ & 56 & 5.43 & 1.01 & $3-7$ & 56 \\
Negative Climate (reversed) & 6.89 & 0.31 & $6-7$ & 56 & 6.91 & 0.29 & $6-7$ & 56 \\
Teacher Sensitivity & 5.41 & 0.80 & $3-7$ & 56 & 5.21 & 0.82 & $4-7$ & 56 \\
Regard for Child Perspectives & 4.41 & 1.04 & $2-6$ & 56 & 4.18 & 1.10 & $2-6$ & 56 \\
Behavior Guidance & 4.75 & 0.96 & $2-7$ & 56 & 4.39 & 0.82 & $3-6$ & 56 \\
Facilitation of Learning & 3.96 & 1.13 & $2-6$ & 56 & 3.77 & 1.06 & $2-6$ & 56 \\
and Development & 3.13 & 0.85 & $1-5$ & 56 & 3.21 & 0.93 & $2-5$ & 56 \\
Quality of Feedback & 3.55 & 0.97 & $1-5$ & 56 & 3.80 & 0.98 & $2-6$ & 56 \\
Language Modeling & \multicolumn{7}{|c|}{} \\
\hline
\end{tabular}

Note: $N$ is the total of observations.

Source: own research.

Overall, the results revealed that all CLASS dimensions showed scores in the mid- to high range, although with some significant variation. Both types of provisions scored the highest on the aspects of emotional quality, especially Positive Climate and Teacher Sensitivity. Educational quality was rated lower though, in 
ELySE VAN DE RIET, PAULINE SLOT

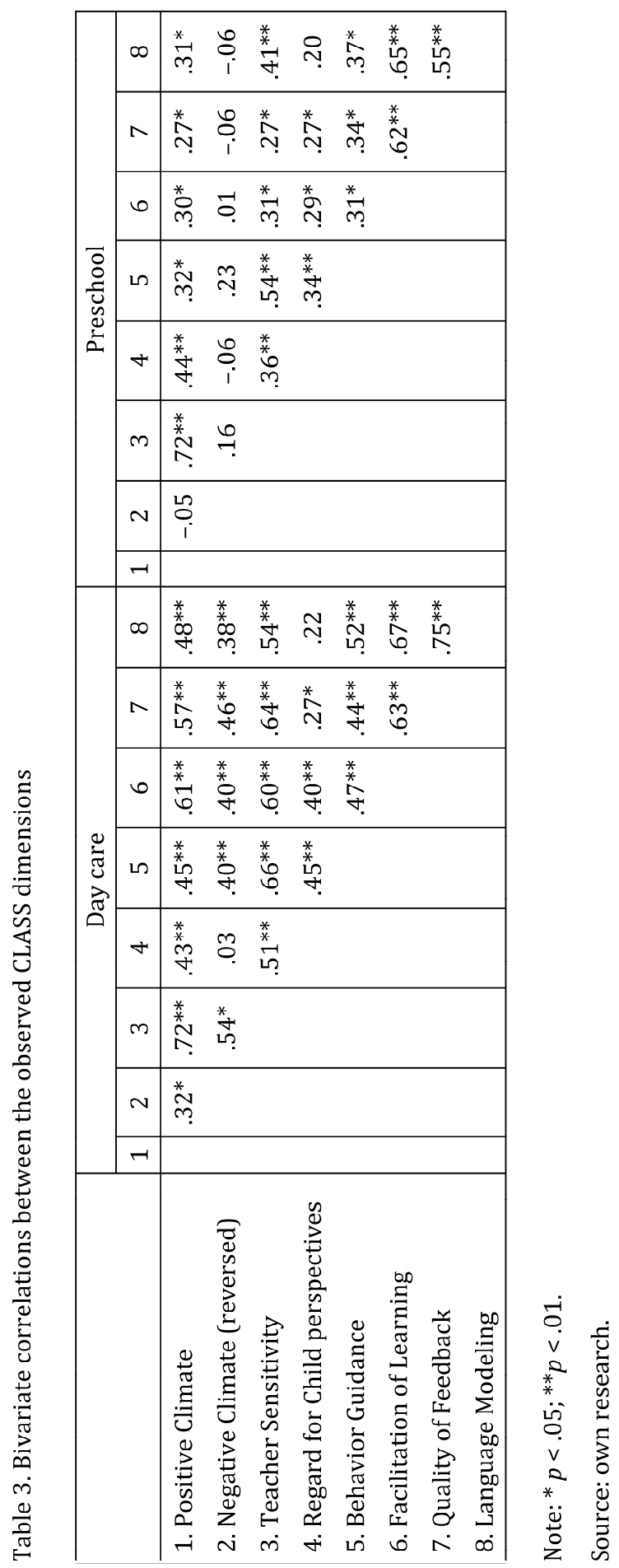

NAUKI O WYCHOWANIU. STUDIA INTERDYSCYPLINARNE

166

NUMER 2017/2(5) 
particular Quality of Feedback. Independent-samples t-tests showed no statistical differences between both types of provisions concerning the mean level of quality. However, there was some variation, both within the type of provision and between the two types of provisions. Generally, day care provisions showed more variation in quality compared to preschools, particularly for the dimensions Teacher Sensitivity, Behavior Guidance, and Quality of Feedback. Moreover, the range of scores in day care provisions was more skewed towards the lower end of the distribution compared to preschools.

Table 3 shows the bivariate correlations between the CLASS dimensions for both types of provisions. The correlations of the CLASS dimensions were low to moderate, mostly significant and generally in the expected direction. However, for the preschool provision, the dimension Negative Climate is mainly negatively correlated to the other dimensions, which is probably related to the limited variability in this dimension. Positive Climate and Teacher Sensitivity showed the strongest correlation in both day care and preschool provisions. Also, the correlations between the educationally oriented dimensions (i.e. Facilitation of Learning and Development, Quality of Feedback, and Language Modeling) were strong. Interestingly, there were moderate correlations between emotionally supportive quality dimensions (i.e. overall classroom climate and teacher sensitivity) with the educationally oriented quality dimensions, especially for day care provisions. Surprisingly, Regard for Child Perspectives showed the smallest correlations with the emotionally and particularly educationally oriented dimensions in both types.

\section{Developmental and pre-academic activities}

Descriptive statistics on the provided developmental and pre-academic activities are presented in Table 4.

Table 4. Descriptive statistics on the provided developmental and pre-academic activities

\begin{tabular}{|l|c|c|c|c|c|c|c|c|}
\hline & \multicolumn{4}{|c|}{ Day care } & \multicolumn{5}{c|}{ Preschool } \\
\cline { 2 - 9 } & $M$ & $S D$ & Range & $N$ & $M$ & $S D$ & Range & $N$ \\
\hline Teacher's questionnaire & & & & & & & & \\
Pretend play & 5.38 & 1.22 & $3.50-7.00$ & 25 & 5.39 & 0.94 & $3.25-7.00$ & 21 \\
Self-regulation & 5.27 & 1.08 & $3.00-7.00$ & 25 & 5.60 & 0.87 & $2.64-6.55$ & 21 \\
Science activities & 3.37 & 1.37 & $1.29-6.29$ & 25 & 3.33 & 1.18 & $1.57-5.43$ & 20 \\
Math activities & 4.50 & 1.46 & $1.64-6.58$ & 25 & 4.94 & 0.79 & $3.17-6.80$ & 21 \\
Language activities & 5.52 & 1.15 & $3.71-7.00$ & 22 & 5.99 & 0.61 & $4.57-7.00$ & 21 \\
Pre-literacy activities & 5.32 & 1.19 & $3.50-7.00$ & 22 & 5.17 & 0.90 & $3.25-6.50$ & 21 \\
\hline
\end{tabular}

Source: own research. 
Teachers' reported a higher level of support for pretend play, self-regulation and more frequent provision of language activities compared to the provision of pre-literacy, math and science activities in both day care centers and preschools. The independent-samples t-tests showed no significant differences between day care and preschool classrooms. However, there was some variation in the reported activities, especially for science and math activities, showing that these activities were hardly provided by some teachers, but more frequently by other teachers.

Table 5 shows the bivariate correlations between the provided activities for both types of provisions. The correlations of the provided activities were low to high, mostly significant and in the expected direction.

Table 5.

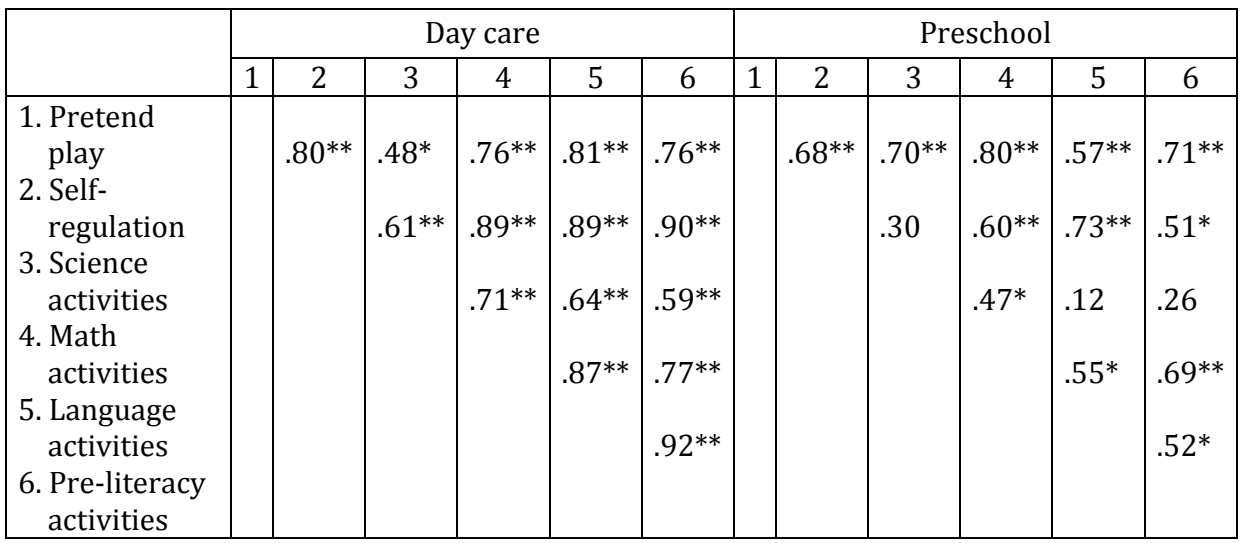

Note: ${ }^{*} p<.05 ;{ }^{* *} p<.01$.

Source: own research.

\section{Discussion}

The importance of ECEC quality for children's development has been well established (Broekhuizen et al. 2015: 226; Burchinal et al. 2010: 166; Cadima et al. 2010: 474; Côté, et al. 2013: 761; Curby et al. 2013: 304; Mashburn et al. 2008: 743; Pianta et al. 2009: 49; Sylva et al. 2011). Hence, the present study investigated the structural, process and curriculum quality in Dutch ECEC provisions considered to reflect good practices. The Dutch ECEC system distinguishes two types of provisions with day care centers targeting children at the age of from three months to four years from working, usually higher educated, parents, whereas preschools provide a half-day program for two-to-four-year-olds, usually from disadvantaged backgrounds. Given the population-related differences between these two provisions, the current study investigated whether the structural features and process and curriculum quality varied between day care and preschool classrooms. 


\section{Structural quality}

The results concerning structural quality revealed that the group size, children-toteacher ratio, and teachers' pre-service education level are in line with the regulations stipulated in the Dutch Childcare Act of 2005. The Netherlands has a strongly regulated ECEC system of average structural quality, according to the comparative review by the Organization of Economic Cooperation and Development of the statutory group sizes, children-to-teacher ratios and required teacher education level in 20 countries (OECD 2006: 131). The results reveal that the two types of provisions did not differ in the average group size. However, there was a significant difference in the children-to-teacher ratio, which was more favorable in day care centers. In the Netherlands, the ratio is defined depending on the age of children; hence these differences can be explained by the fact that day care classrooms consisted of younger children. Further, both types of provisions differ in classroom compositions. In day care classrooms, the majority of children were Dutch, whereas in preschools, the classrooms were more mixed. This can be explained by the fact that preschool provisions use education programs as part of a targeted approach to combat inequality in children with immigration background or from lower educated parents (Akgündüz, Plantenga 2012: 2). There also appeared differences between day care and preschool provisions regarding the educational background of teachers. In the current study, preschools more often employed teachers with higher vocational training compared to day care centers. Finally, the provisions differed in the age composition of the classroom for the simple reason that day care provisions provide care for children in the age range of zero to four years, whereas preschools only enroll two- and three-year-olds.

\section{Process quality}

The process quality in Dutch ECEC was, on average, moderate to high for Emotional Support and moderate for Support for Learning. This pattern is in line with the previous findings from Dutch ECEC studies (Helmerhorst et al. 2014: 784; 2015: 101; Slot et al. 2015: 72; 2017: 89), as well as from other countries, such as the United States (La Paro et al. 2014: 887; Thomason, La Paro 2009: 296). The mean scores were slightly higher in the current study compared to the findings from a larger and more representative sample of Dutch ECEC provisions (Slot et al. 2015: 68; 2017: 83). Particularly striking are higher scores on Positive Climate and the lack of Negative Climate. Interestingly, the scores for Behavior Guidance in the current sample were slightly lower than in the representative Dutch sample (Slot et al. 2015: 68; 2017: 83). The combination of the lack of Negative Climate and lower scores on Behavior Guidance might suggest that due to an overall positive classroom climate fewer behavioral redirections were needed, resulting in lower scores for Behavior Guidance. 
The relations between the different quality dimensions showed that a higher positive climate with a more responsive teacher was related to better support of children's development and learning by providing learning opportunities and fostering language use. The results also showed that the overall child-centeredness was slightly lower and showed weaker relations with particularly educationally oriented aspects of quality. This finding is consistent with the previous Dutch and international research revealing some tension in adopting a very strong childcentered approach, while at the same time providing optimal support for children's learning, which may be related to the particular type of activity the children are involved in (Slot et al. 2015: 68; 2017: 83). It would be interesting for future studies to look into this issue further.

Further, there appeared no significant differences in quality between day care and preschool classrooms. These findings are in contrast with a previous study conducted in a larger and more representative Dutch sample that showed lower educational quality for day care centers (Slot et al. 2017: 89). This difference may be explained by the fact that the current study targeted good practices in ECEC, which resulted in selecting classrooms with, on average, higher educational quality. Although there were no significant differences in the mean scores, the pattern of scores showed some differences regarding educational quality. In day care classrooms, the distribution of scores was more skewed towards the lower end for the dimensions Quality of Feedback and Language Modeling compared to preschool classrooms. The slightly stronger educational focus of preschools may reflect the older age of the children and the more targeted approach of combating early disparities in children given the more culturally diverse population of children attending these preschools (Slot et al. 2015: 70; Veen, Leseman 2016: 115). However, the differences appeared small and, altogether, the findings seem to point to a shift towards higher educational quality that is taking place in the ECEC sector in the Netherlands.

\section{Curriculum of the provided developmental and pre-academic activities}

The teachers participating in the current study reported placing the greatest emphasis on pretend play, self-regulation and language activities, whereas math, pre-literacy and science activities were provided less often, which holds particularly for the latter. There appeared no significant differences between day care and preschool classrooms. A comparison of the present results to the previously reported findings from a larger and more representative Dutch sample shows that the current participants reported providing all types of activities more frequently (Slot et al. 2015: 68), which reflects an increasing educational orientation in both day care and preschool centers in the Netherlands. 


\section{Limitations}

There are several limitations to the current study. First, the participating ECEC centers were selected by the researchers based on good practices and concerned a small sample; hence the findings cannot be generalized. Nevertheless, the results indeed confirm that these centers are good practices, which can inform practice in view of raising quality. Second, the current study did not address the relations between structural quality characteristics and process quality. More research is needed to gain a better understanding of the possible explanatory factors of higher process quality. Finally, the current study did not investigate the relations of quality with child outcomes, and therefore it does not provide insights into possible positive effects of higher quality. It is worth noting however, that a larger Dutch cohort study that is more representative of the overall quality in Dutch ECEC showed positive effects of higher process and curriculum quality both in the short and in the longer term.

\section{Conclusion}

The current study aimed to investigate structural, process and curriculum quality in day care and preschools provisions considered to be good practices. The results showed few differences in structural quality compared to the previously reported findings from a larger and more representative sample, illustrating the strong regulations concerning these aspects in the Netherlands. However, the results on process and curriculum quality indeed confirm that the current centers can be considered good practices given the higher quality. Although previous studies had shown differences in quality between day care facilities and preschools, pointing to a stronger educational orientation for the latter, the current findings indicated no significant differences. This seems to reflect a shift in orientation that was intended with the recently implemented Act OKE (Promoting Development through Quality and Education). However, also within the current study of good practices some significant variation in process and curriculum quality was observed and more research is needed to explain these differences.

\section{References}

Burchinal M. R., Vandergrift N., Pianta R. C., Mashburn A. J. (2010) Threshold analysis of association between child care quality and child outcomes for low-income children in pre-kindergarten programs, "Early Childhood Research Quarterly", 25/2: 166-176.

Broekhuizen M. L., van Aken M. A. G., Dubas J. S., Mulder H., Leseman P. P. M. (2015) Individual differences in effects of child care quality: The role of child affective selfregulation and gender, "Infant Behavior and Development", 40: 216-230. 
Cadima J., Leal T., Burchinal M. (2010) The quality of teacher - student interactions: Associations with first graders' academic and behavioral outcomes, "Journal of School Psychology", 48/6: 457-482.

Clements D. H., Sarama J. (2007) Effects of preschool mathematics curriculum: Summative research in the Building Blocks Project, "Journal for Research in Mathematics Education", 38/2: 136-163.

Curby T. W., Brock L. L., Hamre B. K. (2013) Teachers' emotional support consistency predicts children's achievement gains and social. Skills, "Early Education and Development", 24/3: 292-309.

Côté S. M., Japel C., Séguin J. R., Mongeau C., Xu, Q., Tremblay R. E. (2013) Child are quality and cognitive development: Trajectories leading to better preacademic skills, “Child Development", 84/2: 752-766.

Dickinson D. K., Caswell L. (2007) Building support for language and early literacy in preschool classrooms through in-service professional development: Effects of the Literacy Environment Enrichment Program (LEEP), "Early Childhood Research Quarterly", 22/2: 243-260.

Domitrovich C. E., Cortes R. C., Greenberg M. T. (2007) Improving young children's social and emotional competence: A randomized trial of the preschool PATHS curriculum, "The Journal of Primary Intervention", 28/67: 67-91.

Domitrovich C. E., Gest S. D., Gill S., Bierman K. L., Welsh J. A., Jones D. (2009) Fostering high-quality teaching with an enriched curriculum and professional development support: The Head Start REDI Program, "American Educational Research Journal", 46/2: 567-597.

Fantuzzo J. W., Gadsden V. L., McDermott P. A. (2011) An integrated curriculum to improve mathematics, language, and literacy for Head Start children, "American Educational Research Journal", 48/3: 763-793.

Helmerhorst K. O. W., Riksen-Walraven J. M. A., Gever Deynoot-Schaub M. J. J. M., Tavecchio L. W. C., Fukkink R. G. (2015) Child care quality in The Netherlands over the years: a closer look, "Early Education and Development", 26/1: 89-105.

Helmerhorst K. O. W., Riksen-Walraven J. M. A., Vermeer H. J., Fukkink R. G., Tavecchio L. W. C. (2014) Measuring the interactive skills of caregivers in child care centers: development and validation of the caregiver interaction profile scales, "Early Education and Development", 25/5: 770-790.

Lonigan C. J., Farver J. M., Philips B. M., Clancy-Menchetti J. (2011) Promoting the development of preschool children's emergent literacy skill: A randomized evaluation of a literacy-focused curriculum and two professional development models, "Reading and Writing", 24: 24, 305-337. 
La Paro K. M., Hamre B. K., Pianta R. C. (2011) Classroom Assessment Scoring System Toddler manual, Charlottesville VA, Teachstone.

La Paro K. M., Williamson A. C., Hatfield B. (2014) Assessing quality in toddler classrooms using the CLASS-Toddler and the ITERS-R, "Early Education and Development", 25/6: 875-893.

Leseman P. P. M., Slot P. L. (2013) Kwaliteit en curriculum van voorschoolse opvang en educatie in Nederland: relaties met structurele kenmerken, organisatiekenmerken en educatieve programma's [Quality and curriculum of early childhood education and care in the Netherlands], Utrecht University, Department of Special Education.

Leseman P. P. M., Veen A. (eds) (2016) Ontwikkeling van kinderen en relatie met kwaliteit voorschoolse instellingen. Resultaten van het pre-COOL onderzoek [Development of children and the relation with early childhood education and care quality. Results of the pre-COOL study], Amsterdam, Kohnstamm Instituut, Report 947.

Mashburn A. J., Pianta R. C., Hamre B. K., Downer J. T., Barbarin O. A., Bryant D., Howes C. (2008) Measures of classroom quality in prekindergarten and children's development of academic, language, and social skills, "Child Development", 79/3: 732-749.

Mulder H., Boom J., Slot P. L., Verhagen J., Leseman P. P. M. (2016) Selectieve aandacht [Selective attention] in: P. P. M. Leseman, A. Veen (eds) (2016) Ontwikkeling van kinderen en relatie met kwaliteit voorschoolse instellingen. Resultaten van het pre-COOL onderzoek [Development of children and the relation with early childhood education and care quality. Results of the pre-COOL study], Amsterdam, Kohnstamm Instituut, Report 947.

Nederlands Consortium Kinderopvang Onderzoek (NCKO) [Dutch Consortium for Child Care Research] (2011) Pedagogische kwaliteit van de kinderopvang en de ontwikkeling van jonge kinderen: een longitudinale studie. [Pedagogical quality of Dutch child care en de development of young children: a longitudinal study], NCKO, Amsterdam/Nijmegen.

Pakarinen E., Lerkkanen M.-K., Poikkeus A.-M., Kiuru N., Siekkinen M., Rasku-Puttonen H., et al. (2010) A validation of the Classroom Assessment Scoring System in Finnish kindergartens, "Early Education and Development", 21/1: 95-124.

Pianta R. C., Barnett W. S., Burchinal M., Thornburg K. R. (2009) The effects of preschool education: What we know, how public policy is or is not aligned with the evidence base, and what we need to know, "Psychological Science in the Public Interest", 10/2: 49-88.

Slot P. L., Boom J., Verhagen J., Leseman P. P. M. (2017) Measurement properties of the CLASS Toddler in ECEC in The Netherlands, "Journal of Applied Developmental Psychology", 48: 79-91. 
Slot P. L., Broekhuizen M. L., Leseman P. P. M., Veen A. (2015) Kwaliteit van voorzieningen en effecten op ontwikkeling van kinderen [Quality of provisions and effects on children's development] in: P. P. M. Leseman, A. Veen (eds) (2015) Pre-COOL Cohortenonderzoek. Resultaten over de voorschoolse periode [Pre-COOL study. Results of the early childhood period], Amsterdam, Kohnstamm Instituut, Report 932.

Slot P. L., Leseman P. P. M., Mulder H., Verhagen J. (2013) Handleiding CLASS Toddler [Manual CLASS Toddler], Utrecht, Universiteit Utrecht, Onderwijsadvies en Training.

Slot P. L., Leseman P. P. M., Verhagen J., Mulder H. (2015) Associations between structural quality aspects and process quality in Dutch early childhood education and care settings, "Early Childhood Research Quarterly", 33/4: 64-76.

Suchodoletz A. von Fäsche A., Gunzenhauser C., Hamre B. K. (2014) A typical morning in preschool: Observations of teacher-child interactions in German preschools, "Early Childhood Research Quarterly", 29/4: 509-519.

Sylva K., Melhuish E., Sammons P., Siraj-Blatchford I., Taggart B. (2011) Pre-school quality and educational outcomes at age 11: low quality has little benefit, "Journal of Early Childhood Research", 9/2: 109-124.

Sylva K., Pastori G., Lerkkanen M., Ereky-Stevens K., Slot P. L. (2016) Integrative Report on a culture-sensitive quality \& curriculum framework, University of Jyväskylä, CARE, Curriculum \& Quality Analysis and Impact Review of European Early Childhood Education and Care.

Thomason A. C., La Paro K. M. (2009) Measuring the quality of teacher - child interactions in toddler child care, "Early Education and Development", 20/2: 285-304.

Verhagen J., Mulder H., Boom J., Hoofs H., Slot P. L., Leseman P. P. M. (2016) Woordenschat [Vocabulary] in: P. P. M. Leseman, A. Veen (eds) (2016) Ontwikkeling van kinderen en relatie met kwaliteit voorschoolse instellingen. Resultaten van het preCOOL onderzoek [Development of children and the relation with early childhood education and care quality. Results of the pre-COOL study], Amsterdam, Kohnstamm Instituut, Report 947.

\section{Websites}

Akgündüz Y., Plantenga J. (2012) Equal Access to High Quality Child Care in the Netherlands. Paper prepared for the conference Equal Access to Child Care: Providing Quality Early Years Education and Care to Disadvantaged Families London. Retrieved on 22-02-2017 on http://sticerd.lse.ac.uk/dps/case/events/Netherlands.pdf

Centraal Bureau voor de Statistiek (2016) Retrieved on 22-02-2017 from https://www.cbs.nl/nl-nl/nieuws/2016/34/nederlandse-ouders-gebruiken-vaakstkinderopvang-in-eu 
Convenant Kwaliteit Kinderopvang en Peuterspeelzalen (2013) Retrieved on 22-022017 from http://www.boink.info/media/a5a32bc6/Convenant\%20december\% 202013\%20definitief.pdf

Organisation for Economic Co-operation and Development [OECD] (2006) Starting Strong II: Early childhood education and care. Retrieved on 17-03-2017 from https://www.unicef.org/lac/spbarbados/Implementation/ECD/StartingStrongII_OE CD_2006.pdf

Organisation for Economic Co-operation and Development [OECD] (2015) Starting Strong IV: Monitoring Quality in early childhood education and care. Retrieved on 02-04-2017 from http://www.sel-gipes.com/uploads/1/2/3/3/12332890/2015_-_ocde_ -_starting_strong_iv_monitoring_quality_in_early_childhood_education_and_care.pdf

Portegijs W., Brakel M., van den Hartgers M., Akkermans M. (2016) Emancipatiemonitor 2016. The Hague, The Netherlands, Sociaal en Cultureel Planbureau, Centraal Bureau voor de Statistiek. Retrieved on 22-02-2017 from http://www.scp.nl/ 